MAGDALENA GRELA-CHEN ${ }^{1}$

\title{
GEISHA FEVER: CHANGES IN THE TRADITIONAL ENTERTAINMENT DISTRICTS IN KYOTO IN RESPONSE TO EXCESSIVE ATTENTION FROM WESTERN TOURISTS
}

\begin{abstract}
In the popular discourse, geiko districts are described as places where traditional culture is preserved in a living form. Although this statement may be considered as true, the geiko community is a part of Japanese society as a whole and does not exist in complete isolation. Being able to survive as guardians of the Japanese tradition, in the $21^{\text {st }}$ century geiko are discovering new opportunities, such as using new media to promote themselves in order to protect their lifestyle. However, outside world has forced them to change the way they manage their business in the districts. By using their own Internet sites, Facebook, Twitter and Instagram accounts to reach new customers, they display their daily routine, one in which traditional culture meets modern ideas. This paper shows the reception of usage of the Internet in traditional entertainment districts of Kyoto and the response of Western tourists to the geisha phenomenon. It appears that overwhelming attention on the part of tourist industry, as well as commercialisation, are becoming a threat to the values which have cemented relationships between customers, geiko and teahouses owners. For instance, while during the so-called "geisha hunting", tourists often try to take photographs of them at all costs. Considering the aspects of geiko life and processes mentioned above it is worth analysing how the image of the geiko is perceived by Westerners.
\end{abstract}

Key words: maiko, geiko, Kyoto, stereotypes, commercialisation

${ }^{1}$ PhD Candidate; Jagiellonian University in Kraków; ORCID: 0000-0002-2646-4191; magdalena.grela@vp.pl. 


\section{INTRODUCTION}

Japan can be seen as a land of contrasts. In this land, there are robots of the automated world of the future, shinkansen bullet trains travelling as quick as lightening, colourful subcultures of the younger generation, and the masses of salaryman going to their workplaces. There are also pagodas, temples, Mount Fuji, and cherry trees in full bloom. Finally, there is "she", the geisha, that ambiguous figure so hard to define. She is a myth, she is a symbol, she is a dream, she is everything what one wants to see in her. It seems that everyone knows who she is, and, at the same time, no one is aware of her true nature.

This paper aims to show the relationship between tourists and traditional entertainment districts in Kyoto, called kagai, of which geisha is a staple element. They embrace five quarters, namely: Gion Kōbu, Gion Higashi, Kamishichiken, Ponto-chō and Miyagawa-chō, known by the joint term gokagai ("five flower towns"). Each of them possesses a distinctive atmosphere related to its origins and each is inseparably connected with the old capital's culture and lifestyle. These districts are also a workplace for the geiko and the maiko, the geiko's apprentice (Mizobuchi, 2002, p. 5). In Japan, the terms geiko and geisha are territorially related. Geishas work in quarters of Tokyo' ${ }^{2}$, while geiko operate in Kyoto. In order to embrace all communities sharing the same occupation, the term geigi is used (Nishio, 2007, p. 14).

The examples under consideration have been chosen to demonstrate the situation in Kyoto, and to portray some of the ways in which the districts cope with contemporary challenges. The outside world, including foreign tourists, have caused changes in the traditional entertainment industry's business strategies. At the same time, geiko communities are also introducing changes in order to survive. It appears that the media has become a tool in their hands in order to establish contact with the rest of the world. Moreover, there is a question of the excessive commercialisation of kagai in order to meet the demands of the tourist industry. This conflict of interests may pose a threat to traditional values which bond the geiko community together.

${ }^{2}$ For the purpose of this paper, the term "geisha" will be used when describing the Western perception and image. 


\section{MYSTERY, MYTH AND BEAUTY}

Over time, while looking for a perfect definition of the geisha, it appears that the question of how a geisha is seen and who sees her has become increasingly important. Impressions and stereotypes, repeated and replicated, have led to the misunderstanding of the essence of being a geiko. As a result, there is the geiko's truth about themselves, the ambivalent opinions of Japanese society, and finally the Western image.

Edward Said in Orientalism (1979) shows how the Occident created an image of the Orient. Although his works are based mostly on cases from Arabic countries, the East Asian nations were also orientalised by the West. Kawaguchi Yoko's Butterfly's Sisters (2010) presents a concept similar to that of Said's, yet it is focused on the portrayal of Japanese women, especially geisha figures, in popular culture. Kawaguchi examines various examples which show extreme characteristics of a geisha who can act as a glorified star, while also being able to sacrifice herself. She can be weak, or have a brave nature, can be humble or be acutely aware of her sexuality (Kawaguchi, 2010, pp. 1-11). Shibusawa $(2006$, p. 12) indicates that "the notion of the geisha - a very marginal cultural institution in Japanese society - was central to postwar America's vision of Japan". The American film industry gladly used geisha heroines in several ways. Marchetti (1994, pp. 178-179) states that popularity of this motif in the USA during the postoccupation Japan period was, on one hand, the sign of reconciliation, while on the other, changing the perception of Japan to a more subordinate one. The brave spirit of the Japanese past was overshadowed by the mysterious, yet submissive women. Hollywood films used oriental visions of Japan created in the $19^{\text {th }}$ century, in which geisha and the blooming cherry were paired as a set, to sell new productions. The described world seemed to be the white man's paradise, where an exotic beauty readily chooses him as superior to all other men. As a by-product, Japan found itself in the eye of consumer interest (Shibusawa, 2006, pp. 273-274). Perkins, in Geisha of Pontocho published in 1954, observes two essential points of a foreigner's journey to Kyoto that can be summarised as "first the temples, shrines and souvenirs, and second a Geisha party". He points out that a potential customer's imagination draws a fanciful scene of dance combined with striptease as a part of the prepared amusement (Perkins \& Haar, 1954, p. 13). The film industry was not the only medium which helped to sustain stereotypical images. In the US edition of the fashion magazine Vogue, in the 
issues published between July 1997 and June 2008, the geisha figure embodied traditional aesthetics; she was an artist but at the same time, she was not free from an exoticising gaze (Choi, Medvedev, Lee \& Hunt-Hurst, 2009, p. 8). As far as travel writing is concerned, there is a high possibility of finding the geisha portrayed in its pages, as Berger observed in 2010. She is the foreigner's fantasy, a continuation of a mythical Japan; she becomes the symbol of what a tourist wants to find, namely "that imagined Japan" they are looking for (Berger, 2010, pp. 61-62, 65).

Analysing the place of geigi in Japanese culture, Crihfield Dalby (1983, pp. 172-173) acknowledges their ambiguity. For this society, geigi can be proudly put in the spotlight, when needed, to entertain foreign guests or reveal to the public their personal experience. At the same time, the thought that their own daughters might choose this way of life would not be at all pleasant. Foreman (2005, p. 33) identifies the choice of artistic career over family duties as the main factor that shows these women in a bad light. This is why, generally speaking, it would be an unlikely choice of occupation for a respectable woman.

Considering the voices from geigi themselves, Foreman formulated two definitions. The first, presenting the community point of view states that:

Geisha are women who are officially registered as geisha, geiko, or geigi through a central kumiai ${ }^{3}$ office affiliated with each separate hanamachi geisha district. Furthermore, geisha are defined as those actively studying music and/or dance within the community of teachers associated with that hanamachi, and they are actively involved with the performances associated with that hanamachi and its group of teachers. (Foreman, 2008, p. 3)

This definition focuses on the official character of being a geigi and on fulfilling her artistic career path under the guidance of teachers accredited by the community to which she belongs. The other presents a broader view of the geigi's activities, mentioning being registered in a central office and studying music and dance. It says that geigi "perform music and dance for parties in order to pay for their art lessons and elaborate public stage performances" (Foreman, 2005, p. 34). The other point of view does not overlook the economic aspect of the profession, treated as a source of income for these women.

\footnotetext{
${ }^{3}$ A geisha union (Foreman, 2008, p. xi).
} 


\section{CHASING THE SYMBOL OF KYOTO}

Commercialisation of the geiko image involves difficulties in understanding the characteristics of the occupation of geiko by visitors. It should be noted that the scale of this problem is not limited only to incidents caused by foreigners coming to the old capital, but it includes also those caused by the Japanese themselves (Johnston, 2009). One of the biggest challenges is the growing popularity of the so-called "geisha hunting" phenomenon. This term is used in popular discourse to describe the behaviour of tourists who are practising a new form of "safari" on the streets of traditional entertainment districts. Their main goal is not only to see maiko, the object of their desire, but also to take a photograph of them as a trophy. In this game, a tourist plays the role of a hunter, equipped with a camera or a smartphone, chasing not an animal, but a living human being.

How do common people know about the "geisha hunt", and how does this idea spread? An English-speaking Internet user is able to learn the basics from tourist guides and traveller sites without any difficulty. One of the examples can be The Passport Lifestyle which offers The insider's guide to geisha hunting in Kyoto. Beside sharing advice about the most suitable locations and time to notice a geiko, its author explains her point of view. Potential tourists can read that "seeing a geisha in Japan is like spotting a tiger in the wild in Thailand; viewing them in their native environment is just far more beautiful. It's magical" (Stephanie, 2016). They are invited "to do something unique and exciting in Japan" (Castillo, 2016), encouraged by reading the previous participant's memories, whose "mind stopped for a moment" after seeing a dazzling maiko (McCulley, 2013). It seems that a large number of people try to catch a glimpse of geiko at all costs, creating an uproar, along with dangerous situations such as pushing or barring the path of maiko who are in a hurry, wearing platform shoes and a heavy outfit. Also problematic are the cases of tourists invading geiko's private space, by following them and getting into physical contact. Such people have also been known to touch a maiko's elaborate coiffure or luxurious costume, which may be irretrievably ruined. In response to such actions, the local community has decided to protect geiko and maiko by forming special patrols to monitor the situation on the streets and ensure safe passage for the geiko (Johnston, 2009; Tanikawa, 2009). Beside these initiatives, official campaigns managed by Kyoto City Tourism Association can be observed, such as placing an appeal aimed at tourists in the 
entertainment section of the association's official site, calling them to respect the maiko's privacy, or issuing of the Akimahen of Kyoto etiquette guide flyers informing them how not to behave towards geiko. These leaflets describe in a simple way what is considered as an example of inappropriate behaviour while spending time in Kyoto, including harassing maiko on the streets (Kyoto City Tourism Association, n.d.).

However, the tourist has become a new type of a customer whose will to interact with geiko cannot be negated. It appears that traditional entertainment districts are trying to meet the visitors' expectations by offering them some special kinds of entertainment. One of the locations where visitors can see a short performance held by maiko, and also enjoy the exhibition of hair accessories or see dance performances, is the Gion Corner. A Kyōmai ${ }^{4}$ show is a part of the program there, in which a few types of traditional art performances may be seen (Ookini Zaidan, n.d.). Nishio (20102011a, p. 10) observes that the tourist who watches such shows is offered culture presented "in an easy-to-understand way". A similar project, named Maiko Theatre and devoted entirely to introducing geiko culture to tourists, has been operated by Shigemori ochaya in Miyagawa-chō, since December 2016. The okāsan's main goal is to allow foreigners and younger Japanese generations discover this aspect of Japanese culture (Tsubone-ana net, 2017). This example shows that the families which run teahouses are starting to manage additional enterprises, with more commercial characteristics, which let them expand their existing income sources. This decision provides a possibility to benefit from a new group of customers, while maintaining the prestige of the teahouse itself, as well as its established rules.

However, the discord between fixed, unwritten rules concerning customer-teahouse relations and tourists' requirements is becoming a challenge for teahouse owners. Aihara (2012, pp. 121-123) indicates that every ochaya treasures a long-term relationship with customers based on mutual trust. Even if nowadays gaining entry to ozashiki ${ }^{6}$ for ichigensan ${ }^{7}$

${ }^{4}$ One of the styles of traditional Japanese dance. Kyōmai is taught by Inoue school and practiced by geiko and maiko working in Gion Kōbu (Sugita \& Mizobuchi, 2003, p. 81).

${ }^{5} \mathrm{~A}$ title given to a proprietress of an ochaya (teahouse), meaning literally "mother" (Hanawa, 2007, p. 47).

${ }^{6} \mathrm{~A}$ party being held in an ochaya with a maiko and geiko companion (Foster, 2009, p. 42).

${ }^{7}$ A new customer who is unfamiliar with the teahouse, thus, according to the rules is not allowed to participate in a party (Sato, 2006, p. 93). 
is becoming easier, it does not automatically signify that all of the community welcomes these changes easily. One of the reasons is the character of the teahouse itself, which is not only a place to run a business, but also a home for the proprietress, young maiko and geiko. Despite this, examples of teahouses which practice an open-door policy for two types of customers may be observed. For instance, Gion Higashi's Tomikiku ochaya openly invites new customers who would like to enjoy geiko hospitality, to make reservation for "a special plan" celebration. The transparency of the fixed product on offer, including the prices, or a possibility to negotiate a plan for students, are its strong points. At the same time, luxury banquets on regular basis, accessible only by recommendation of a long-time customer, are held (Tomikiku, n.d.). Furthermore, hotels aim to meet the expectations of tourists who do not want to attend a party at an ochaya. A representative example may be Gion Hatanaka Ryokan. By choosing this option, a customer is able to book a room for a night and a meeting with maiko, as an addition to his reservation, or he can also visit the place only for this purpose. The attraction on offer is called a Kyoto Cuisine \& Maiko Evening, and allows tourists experience the company of geiko. Foreign customers are supported by English-speaking staff who will help them communicate with the maiko. There is also a possibility of making a payment by credit card (Gion Hatanaka, n.d.). This form of payment is not accepted in the Tomikiku ochaya (Tomikiku, n.d.). As Nishio (2010-2011b, pp. 61-62) states, none of the Kyoto teahouses honours cards. Moreover, a transaction is finalised later in order to lighten the customer's burden on the day of planned gathering, which is also a natural extension of longterm relationships with customers, in which trust is the foundation of everything. Furthermore, according to Aihara (2012, pp. 121-122), the final price of a banquet is difficult to predict due to many variables. Okāsan calculates the price of the food served, the length of a party, the number of geiko etc. while having in mind customers themselves. It seems that two patterns have started to emerge at the same time, namely one for long-term patrons and the other for occasional customers. Such an evolution in the scheme involving money transactions is a revolutionary step in the kagai. Thus, it is another consequence of opening this world to onetimers. New type of offers, with pre-determined costs or requirements to pay in advance, is a contradiction of the traditional approach to business matters. 


\section{A NEW PLATFORM OF COMMUNICATION}

It has come to light that kagai from Kyoto have started to feel that they have become the object of an intensified interest from the media. Although the geiko Kimina argues that "there is a new trend to save the traditional maiko and geiko world in society right now", she remains aware of the recipient's understanding often acquired from media sources, giving him a false impression of possessing profound knowledge (Foster, 2009, p. 65). While voices like this create an impression that an outside world is knocking on the doors of vanishing traditional entertainment districts, it appears that kagai members are also interacting more and more actively with the rest of the society. One of the milestones was the creation of a website by the geiko Koito from Miyagawa-chō, in 1996. As her intention was to prevent geiko culture from vanishing, it was met with warm welcome from the public (Sato, 2006, p. 97). Koito was the first to unveil the mystery of the maiko's daily life via the Internet. Downer observed that the maiko Komaki who, as debuted by Koito, "was the first maiko of the cyber age". Komaki's journey, from "dreams come true" to the struggle with her daily routine, showed the pros and cons of this career choice (Downer, 2002, pp. 177-178). As this example presented an alternative way of communication, some other members of the community followed in Koito's footsteps. Kamishichiken Ichimame was another Internet star whose online activity was noted worldwide. On her blog, she described her routine as including music and dance lessons (Rook, 2007). The idea of hosting a blog was continued by other maiko who belonged to the same Ichi ochaya as Ichimame. There were two versions available, the standard one in Japanese, and one in English prepared for foreigners (Kamishichiken Ichi, n.d.). Another pioneer blogger is the geiko Miyosaku of Ponto-chō, whose diary contains blog posts uploaded since January 1997 until the present day (Sakuchan Ponto-chō, n.d.). Although written only in Japanese, it is a valuable source of knowledge about the district's life.

Actions undertaken by kagai members may be observed not only through their own websites or blogs, but also on Facebook, Twitter and Instagram. Some of them seem to be individual activities, while others are rather a part of an organised strategy of a specific enterprise. Some of the ochayas have decided to operate on the Internet in a more complex way. The Shigemori ochaya, located in Miyagawa-chō, has prepared a website describing the teahouse and a Morita bar, also belonging to the same 
owners, combined with a blog about their geiko and maiko, preceded by an introduction (Shigemori, n.d.). The Yoshifumi ochaya, besides its own site (Yoshifumi, n.d.), manages accounts both on Twitter (Yoshifumi01, n.d.) and Instagram (kyoto.yoshifumi, n.d.).

The activity of the Koimaiko group may serve as another example of a coordinated and comprehensive campaign. Originated by the Tsurui ochaya of Gion Kōbu in 2008, it began with their cooperation with a songwriter, Madoka Hiroshi. A result of their work was the release of the single Kyōto enren monogatari (Authentic Record, n.d.). The next step was hosting a TV show called Koimaiko no Kyōto bojō, broadcast by the J:COM cable TV station. The show aimed not only to present remarkable places in the old capital, but also to let maiko get closer to ordinary people (Nobuyuki, 2013). The program began to be aired on April 2010, and since 2015, maiko from another ochaya - Odamoto, have also joined the group. Additionally, a paperback guidebook has been published. It contains a short biography of each hosting maiko, and some basic information about the Kyoto maiko's image. The edition contains a CD, with excerpts of the episodes taken from the TV show (Watanabe, 2015). The whole project is linked to an official fan site. Everyone who registers can become a member of their fan club and access unpublished content. There is also an online shop selling souvenirs, such as photographs, bags or postcards (Koimaiko, n.d.). The long-term initiative of Koimaiko has allowed customers to become familiar with certain maiko, and to build some kind of bond with them. The creation of a fan club can indicate the popularity of this group. This may mean that maiko are becoming more and more accessible to the average person.

Becoming a writer is another way for the geiko to convey the values and traditions of kagai. This is a chance to show their point of view and to take complete control of the approach taken in portraying their lifestyle. Autobiographies of geiko who hold the status of the district legends, such as Toyochiyo, are available, albeit written in Japanese (Kiriki, 2007), along with that of Mameji (Arai, 2015), conveying memories of the past. There are also books prepared by relatively fresh kagai members which may be interesting for the young generation. The book prepared by Ichimame (Kamishichiken, 2007), already known to the public due to her blog, describes in a straightforward way maiko etiquette and their daily lifestyle. The autobiography written by the geiko Komomo (Komomo \& Ogino, 2008) has also reached foreign readers. It is available in English translation and depicts the story of a girl who could be described as a citizen of the world, but 
who chooses to return to her fatherland and starts her career in the world of traditional art. Her lucid narration, describing her daily struggles, doubts about her life choices, and successes, shows a typical geiko's life. From the book we learn that they experience emotions and face obstacles, just like any other person. By revealing this, Komomo breaks the wall of inaccessibility, letting common people know the truth about her life in a kagai.

\section{CONCLUSIONS}

After taking a closer look at the development of new forms of entertainment offered in gokagai, it can be said that the product they offer to customers who have not had any previous contact with the community will probably continue to flourish. Indeed, the attention of tourists, when used in the right way, may help to maintain the existence of traditional entertainment districts in a living form. As this process has already started, the gates of such districts have been opened up to anyone who would like to immerse themselves in the geiko world. At the same time, the traditional scheme of things has not disappeared completely. There are still places that strictly follow the old rules, with entry limited only to carefully verified customers. Although new clients are treated with traditional hospitality, some privileges are unattainable for them. The most vivid example may be the differences in the method of payment, depending on the level of mutual trust.

The geisha figure, with all its stereotypes and fantasies, is a magnet which attracts foreigners to Japan. In Kyoto, their expectations have an opportunity to meet reality, while their visions can be confronted with the truth hidden behind the lattice doors of the teahouses. A desire to fulfil their wishes makes them potential recipients of entertainment performed by geiko and maiko. To make the encounter possible, both geiko and teahouse owners have needed to introduce changes in their working practices. A new product on offer must suit a new type of customer, a customer with limited time, resources, knowledge about Japanese culture and lifestyle, as well as the language barrier. The interaction between these two groups of interest proceeds not without difficulties. The "geisha hunting" phenomenon displays the dark side of this process. Thus, the transformation of culturally blind tourists' mass behaviour is becoming the biggest challenge of the present time. Furthermore, educational campaigns undertaken by the 
official institutions, and the explanations provided by geiko themselves, are creating conditions to fight stereotypes. Thus, such visitors who are able to gain this knowledge from original sources may later change their views and become the advocates of truth themselves.

Therefore, geiko communities have reached the point when it is not the lack of attention, but rather excessive interest in them which has become a problem. Letting tourists enjoy their time in the company of maiko is a chance for them to maintain their businesses, by introducing diversity in their income sources, and to benefit from being a symbol of Japan. They have also become more open to new technologies, allowing society to better understand them by running blogs and Internet sites. This opening up to the modern world is a way for them to be seen as a living part of society as a whole. This move can be viewed as hazardous, when confronted with the traditional lifestyle and perceptible spirit of a past once frozen in such a form. On the other hand, it can be seen as a return to the revolutionary origin of the tradition of geiko, who were once trendsetters free to dictate fashion in Japan.

\section{BIBLIOGRAPHY}

Aihara, K. (2012). Kyōto hanamachi maiko to geigi no uchiakebanashi: gei, bi, yū, koi, bungaku uchira no okuzashiki e yōkoso『京都花街舞妓之芸妓のうちあけ話: 芸·美·遊·恋·文学 うちらの奥座敷へようこそ』.Kyōto: Tankōsha.

Arai, M. (2015). Gion mameji chotto mukashi no Gion machi 『祇園豆爾ちょっと昔の祇園町』. Tōkyō: Asahi Shimbun Shuppan.

Authentic Record. (n.d.). Koimaiko『恋舞妓』. Retrieved May 29, 2019, from https://authenticrecord.jp/artist_koimaiko.html

Berger, A. A. (2010). Tourism in Japan. An Ethno-semiotic Analysis. Bristol, Buffalo, Toronto: Chanel View Publications.

Castillo, J. (2016, November 23). Geisha Hunting in Kyoto: How to Spot a Real One. TripZilla. Retrieved June 2, 2019, from https://www.tripzilla.com/geisha-hunting-gion-district-kyoto/ 48788

Choi, Y. J., Medvedev, K., Lee, Y., \& Hunt-Hurst, P. (2009). How China, Japan and Korea Are Perceived by Vogue USA in the Last 10 Years. International Journal of Fashion Design, Technology and Education, 2(1), 3-11.

Crihfield Dalby, L. (1983). Geisha. Berkeley, Los Angeles, London: University of California Press.

Downer, L. (2002). Women of the Pleasure Quarters: The Secret History of the Geisha. New York: Broadway Books.

Foreman, K. M. (2005). Bad Girls Confined: Okuni, Geisha, and the Negotiation of Female Performance Space. In L. Miller \& J. Bardsley (Eds.), Bad Girls of Japan. Houndmills, Balsingstoke, Hampshire-New York: Palgrave Macmillan.

Foreman, K. M. (2008). The Gei of Geisha: Music, Identity and Meaning. Aldershot: Ashgate. 
Foster, J. (2009). Geisha \& Maiko of Kyoto: Beauty, Art \& Dance. Atglen: Shiffer Publishing Ltd. Gion Hatanaka. (n.d.). Kyoto Cuisine \& Maiko Evening. Kyoto Dining with Maiko. Retrieved June 2, 2019, from http://www.gionhatanaka.jp/maiko/english/index.html

Hanawa, C. (2007). One Family's Business. Kateigaho. International Edition: Japan's Art \& Culture Magazine. 15, 44-47.

Johnston, E. (2009). Respect 'Maiko' Privacy, Don't Act Like Paparazzi, Kyoto Tells Tourists. The Japan Times. Retrieved June 2, 2019, from https://www.japantimes.co.jp/news/2009/01/13/ national/respect-maiko-privacy-dont-act-like-paparazzi-kyoto-tells-tourists/

Kamishichiken Ichi. (n.d.). Maiko burogu 『舞妓ブログ』. Retrieved June 2, 2019, from http:// www.ichi-kyoto.jp/

Kamishichiken, I. (2007). Maiko no osahō 『舞妓のお作法』. Tōkyō: Daiwa Shobō.

Kawaguchi, Y. (2010). Butterfly's Sisters. The Geisha in Western Culture. New Heaven, London: Yale University Press.

Kiriki, C. (2007). Aisare jōzu ni naru Gionryū onnamigaki『愛され上手になる祇園流·女磨き』. Japan: Kodansha.

Koimaiko. (n.d). Koimaiko ofisharu fan saito 『恋舞妓おふいしやるふあんさいと』. Retrieved May 29, 2019, from https://koimaiko.jp/

Komomo \& Ogino, N. (2008). A Geisha's Journey: My Life as a Kyoto Apprentice (G. Reidy \& P. Price, Trans.). Tokyo, New York: Kodansha International.

Kyoto City Tourism Association. (n.d.). Kyoto City Official Travel Guide. Retrieved June 2, 2019, from https://kyoto.travel/en

kyoto.yoshifumi. (n.d.). Instagram. Retrieved June 2, 2019, from https://www.instagram.com/ kyoto.yoshifumi/

Marchetti, G. (1994). Romance and the "Yellow Peril". Race, Sex and Discursive Strategies in Hollywood Fiction. Berkeley, Los Angeles, London: University of California Press.

McCulley, K. (2013, September 21). And Then We Saw Her [Web log post]. Retrieved June 2, 2019, from https://www.adventurouskate.com/and-then-we-saw-her/

Mizobuchi, H. (2002). Kyōto Hanamachi: Gion Kōbu, Miyagawachō, Kamishichiken, Pontochō, Gion Higashi『京都花街: 祇園甲部·宮川町·上七軒·先斗町·祇園東』. Kyōto: Mitsumura Suiko Shoin.

Nishio, K. (2007). Kyōto Hanamachi no keieigaku『京都花街の経営学』. Tōkyō: Tōyō Keizai Shinpōsha.

Nishio, K. (2010-2011a). Chapter 1. The Kyoto Hanamachi. The Japanese Economy, 37(4), 6-19.

Nishio, K. (2010-2011b). Chapter 5. No Wallet Required. The Japanese Economy, 37(4), 61-73.

Nobuyuki, N. (2013, December 1). Culture: Maiko Guides Give Kyoto Show a Colorful Twist. The Daily Yomiuri. Retrieved June 2, 2019, from https://www.questia.com/ newspaper/1P3-3151032671/culture-maiko-guides-give-kyoto-show-a-colorful-twist

Ookini Zaidan. (n.d.). Yasaka Hall Gion Corner. Retrieved June 2, 2019, from http://www.kyotogioncorner.com/global/en.html

Perkins, P. D., \& Haar, F. (1954). Geisha of Pontocho. Tokyo: Tokyo News Service.

Rook, D./AFP. (2007, February 1). Ichimame. Apprentice geisha. ThingsAsian. Retrieved June 2, 2019, from http://thingsasian.com/story/ichimame-apprentice-geisha

Said, E. W. (1979). Orientalism. New York: Vintage Books.

Sakuchan Ponto-chō. (n.d.). Saku-chan nikki. Atarashii koto ni chōsen. Yononaka no susumi ni tsuite ikeru yō ni! 『咲くちゃん日記。新しい事に挑戦・世の中の進みについていけるよう に!』. Retrieved June 2, 2019, from http://blog.livedoor.jp/sakutyan7/

Sato, M. (2006). From Schoolgirl in China to Epitome of Japan's Culture. Kateigaho. International Edition: Japan's Art \& Culture Magazine. 11, 93-97. 
Shibusawa, N. (2006). America's Geisha Ally. Reimagining the Japanese Enemy. Cambridge, London: Harvard University Press.

Shigemori. (n.d.). Kyōto Hanamachi Miyagawachō no ochaya Shigemori to bā Morita no maiko, geikonogoshōkai『京都花街宮川町のお茶屋しげ森とバーもり多の舞妓·去妓のご紹介』. Retrieved June 2, 2019, from https://ochaya.kyo2.jp/

Stephanie. (2016, April 13). The Insider's Guide to Geisha Hunting in Kyoto [Web log post]. Retrieved June 2, 2019, from https://www.thepassportlifestyle.com/geisha-hunting-in-kyoto/

Sugita, H., \& Mizobuchi, H. (2003). Kyō no Kagai Gion『京の花街祇園』. Japan: Tankōsha.

Tanikawa, M. (2009, April 6). In Kyoto, a Call to Not Trample the Geisha. The New York Times. Retrieved June 2, 2019, from https://www.nytimes.com/2009/04/07/world/asia/07iht-geisha.html

Tomikiku. (n.d.). Gion Kaiwai Kyōmaiko『祇園界隈京舞妓』. Retrieved June 2, 2019, from http://gion-east.jp/en/tomikiku/index.html

Tsubone-ana net. (2017, January 7). Ichigen-san mo maiko asobi, taiken dekimasu Sawa Tomoka『一見さんも舞妓遊び、体験できます さわともか』. Sankei Biz. Retrieved June 2, 2019, from https://www.sankeibiz.jp/econome/news/170107/ecd1701071500001-n1.htm

Watanabe, S. (ed.). (2015). Koimaiko ga oshieru jimoto no Kyōto: jēkomu koimaiko no Kyōto bojō ofisharu bukku『恋舞妓が教える地元の京都: J:COM<恋舞妓の京都慕情>オフィシ ヤルブック』. Tōkyō: Tatsumi Shuppan.

Yoshifumi. (n.d.). Kyōto Miyagawachō maiko Yoshifumi 『京都宮川町舞妓よし冨美』.Retrieved June 2, 2019, from https://www.kyoto-yoshifumi.com/

Yoshifumi01.(n.d.). Yoshifumi『よし冨美』[Twitter]. Retrieved June2, 2019, from https://twitter. com/YOSHIFUMI01?ref_src=twsrc\%5Etfw\%7Ctwcamp\%5Eembeddedtimeline\%7Ctwterm \%5Eprofile\%3AYOSHIFUMMI01\&ref_url=https\%3A\%2F\%2Fwww.kyoto-yoshifumi.com\%2F 